\title{
Silicate rocks associated with carbonatites in plate-collision settings: their origin, evolution and significance for rare-earth exploration
}

\begin{abstract}
A.R. CHAKHMOURADIAN ${ }^{1}$
${ }^{1}$ Department of Geological Sciences, University of Manitoba, Winnipeg, MB R3T 2N2, Canada

Carbonatitic magmas can be generated in plate-collision settings (PCS) in response to complex tectonic processes and interaction between the subcontinental mantle with subducted crustal material. Although these carbonatites account for $<20 \%$ of all known localities, their economic significance as a source of rare-earth elements (REE) is unparalleled by any other rare rock type, as exemplified by the Mountain Pass deposit in California. Carbonatitic magmatism in PCS has occurred intermittently since the Neoarchean, with peaks of activity conforming to the supercontinent cycles.

Carbonatites in PCS are commonly associated with alkaline silicate rocks, ranging in composition from clinopyroxenites to feldspthatoid syenites or silicaoversaturated alkali feldspar syenites. These intrusive series are derived from alkali-basaltic ("shoshonitic") magmas evolving towards phonolitic or trachydacitic-rhyolitic compositions. Their evolutionary trends are affected by the composition of fractionating clinopyroxene, relative timing of feldspar crystallization, contamination with silica-rich crustal material, and devolatilization. The latter process, as well as apatite \pm zircon fractionation, have a profound effect on their REE budget. The isotopic compositions of alkaline silicate magmas from PCS indciate the importance of crustal contributions to their source regions in the mantle.

Petrogenetic relationship between carbonatites and their associated alkaline rocks have been debated extensively, and the nature of that relationship has far-reaching implications for REE metallogeny. The four principal models (independently evolving magmas, conjugate immiscible liquids, fractionation products, and exsolution of $\mathrm{CO}_{2}$-rich fluids from a silicate melt) should be expected to result in very different geochemical patterns in the two rock series and in recognizable textural characteristics. For example, liquid immiscibility will produce a carbonatitic derivative with higher $(\mathrm{La} / \mathrm{Yb})_{\mathrm{CN}}$ but lower $\mathrm{P} / \mathrm{La}$ ratios than in its silicate conjugate, whereas feldspar fractionation will generate a trend of progressive $\mathrm{Ba}$ depletion and REE enrichment. In this talk, the four models will be compared on a quantitative basis and their feasibility discussed using specific examples.
\end{abstract}

